\title{
1. Introduction to The Handbook of Diverse Economies: inventory as ethical intervention
}

\author{
J.K. Gibson-Graham and Kelly Dombroski
}

When economies are discussed today the looming image is the capitalist economy - the system of production, exchange and finance that has grown exponentially over the last 200 years. It is hard not to be awed by the rapid spread around the globe of market relations and industrial production associated with capitalism. It is also hard not to be alarmed by growing levels of inequality and the devastating environmental impacts that the growth in commodity production, material consumption, population and urbanization has had, especially since the 1950s when what has been dubbed 'The Great Acceleration' took off (Steffen et al. 2015). The research presented in this handbook offers a head-on challenge to narratives that valorize a monolithic neoliberal capitalism and the assumed benefits that are purported to stem from it. It presents a range of strategies for 'doing economy' differently - starting with an understanding of the economy as diverse and heterogeneous (rather than monolithic) and mutable rather than fixed in form. It is our view that empowering and supporting these differences can promote ethical and solidaristic modes of interdependence and help mitigate some of the key challenges of our time (such as environmental destruction and increasing inequality).

Underpinning this handbook is an observation - that the attention given to a monolithic capitalism belies the diversity of economic activities. If 90 per cent of the world's fishing activity is conducted by small-scale fishers (FAO 2015, p. ix), on boats where labour and compensation are organized by community or kin relations, why do so many commentators focus only on the capitalist fishing industry? If almost 10 per cent of the world's employed population (some 274.9 million) work 'in or in the scope of' cooperatives (Eum 2017) and 61 per cent of the employed population (some two billion) work in informal activities and businesses (Bonnet et al. 2019) why do capitalist enterprises command so much attention? If so much care work is done by unpaid workers in homes and neighbourhoods, why is the focus so often on waged employment or its loss or lack? If gifting and reciprocity are used to share wealth and effort, and ethical fair-trade networks are gaining ground, why does economic theory foreground abstracted market exchanges governed by competitive logics of supply and demand? There is something going on with the representation of economies that allows for certain activities to be highlighted and thus valued, and others to be made less visible. The Handbook of Diverse Economies takes up this issue. It introduces a body of work that challenges the ways economies are represented and counters the powerful effect of these framings with research that prompts other imaginaries and actions.

One effect of representing the capitalist economic system as so dominant is that people assume it is insurmountable. Despite the social inequities and degraded ecologies it produces, capitalism appears to many as a system that is here to stay and to which 'there is no alternative' (TINA). Indeed, despite its crises and breakdowns, capitalism appears to be resilient, seemingly immune to revolutionary transformation. At the same time critics point to the way this 'system' fails to cater to the material needs of the majority world, or how the 1 per cent 
benefit while the 99 per cent suffer. Continually describing the many negative effects of capitalism can lead to hopelessness and a sense that as economic subjects we are not able to take responsibility for our world and its forward trajectory. This is a despairing legacy to leave to the next generation of scholars and activists. This handbook presents a different way forward, by highlighting the diversity of economic practices that make up our shared world. In doing so, it opens up the possibility of identifying multiple economic trajectories and discovering the distributed nature of power relations.

The field of research known as 'diverse economies' is quite new, having been first sketched out by feminist economic geographer J.K. Gibson-Graham in 1996 in The End of Capitalism (As We Knew It): A Feminist Critique of Political Economy. While elements of economic diversity are studied in many different disciplinary contexts, what distinguishes diverse economies scholarship is its commitment to theorizing the economy as a site of ethical action. To this end it has generated a discourse of economy that is open to multiplicity and possibility, in which capitalism is not seen as an 'economic system' defined by an essential identity with universalizing dynamics, nor as the most efficient and advanced model of economy. Diverse economies scholarship involves detaching from such powerful structures of thought - ones that continue to inform both those who support and see themselves as benefiting from a capitalist world and those who struggle to replace it with something more equitable and environmentally sustainable. The End of Capitalism (As We Knew It) proclaimed, not an end to the material realities that many associate with capitalist development, but an end to a way of thinking that was beholden to capitalism as the ultimate toe-stubbing 'real' - the bottom line which underpins, determines and constrains action (see the methodology framing chapter by Roelvink, Chapter 50 in this volume). In The End of Capitalism (As We Knew It) and the subsequent book $A$ Postcapitalist Politics which followed a decade after in 2006, Gibson-Graham identified the crucial role that economic experimentation and subjectivity play in adopting such a different stance towards the economy (see the framing chapter on subjectivity by Healy, Özselçuk and Madra, Chapter 43).

In more recent times, there has been a flourishing of diverse economies scholarship investigating and reflecting on the multiple dimensions of economic life, as the following chapters demonstrate. The handbook is organized into seven parts, the first five addressing the 'what' of diverse forms of economic activity (Enterprise, Labour, Transactions, Property and Finance). The sixth part focuses on Subjectivity, the 'who' of diverse economies, and the seventh part addresses Methodology and the 'how' of this approach. Each part contains multiple topic chapters aimed at students who may not be so familiar with economic concepts. At the start of each part is a framing chapter aimed at a more advanced readership that addresses in more depth the theoretical groundings of each section.

This introductory essay looks back on the origins of this new field of study and looks forward to how it is developing in exciting new directions that have implications for action. It begins by elaborating why this kind of scholarship is timely and how it might be used. It briefly discusses the contextual theoretical groundings of this field of study in anti-essentialist Marxian political economy, post-structural feminism, ecological humanities and science and technology studies. It introduces some critical thinking techniques that have been deployed to 'take back the economy'. It elaborates the diverse economies framing and how the practice of inventorying can become a strategy for opening up the economy to exploration, to new kinds of examination and to different kinds of economic subjectivity. It discusses the important role played by inventorying economic diversity in the project of building ethical community 
economies. Finally, it reviews some of the emerging frontiers of research in the field of diverse economies and highlights areas where new scholarship is extending and reshaping the field.

\section{DIVERSE ECONOMIES: WHY NOW? WHO BY? AND WHO FOR?}

All over the world communities and nations are facing economic crises and crises of democracy. Different segments of society are voting and taking actions that are driven by anger and resentment, making their concerns known in myriad and sometimes unpredictable ways. Meanwhile the challenge of addressing climate change requires global cooperation, but standing in the way of change is adherence to established economic paradigms and the inability of governments to act. Young people, even schoolchildren, are on the streets - utterly dismayed with the lack of action by what appears to be a self-interested and myopic older generation. Now, more than ever before, people are calling for a different way of going forward as humans in a multi-species and more than human world (Plumwood 2007).

Numerous blueprints have been proposed for how to fundamentally transform society and build more resilient economies. With state socialism no longer seen as offering an 'alternative' pathway, other paradigms such as sustainable development or degrowth have been suggested. Almost all are premised on a critique of the status quo - of belief in growth for growth's sake, of mindless consumerism, of the drive to accumulate and of corporate control of markets. Or to put it in sharper relief, most are premised on critiques of 'capitalism' and what are seen as its inherent 'systemic' tendencies. The blueprints proposed are thus premised on the need to transcend capitalism and its hegemonic articulation of production, exchange, finance, property, governance, culture and social relations. The term 'postcapitalism' has recently been enrolled (in quite a different register to that used in this handbook), to signal a clean break from the exploitative system of capitalism (Mason 2016). These visions may be inspiring, but pathways to their achievement are only vaguely identified, and the attractions of embarking on such pathways are assumed, without recognizing the very different starting points for people in different situations around the world.

The motivation for diverse economies scholarship is similarly grounded in a critique of the status quo, of business as usual, of capitalist practices that are exploitative and extractive and that, in association with multiple forms of concentrated power, exert undue influence on trajectories of change. But our approach to building postcapitalist futures is very different. Our starting point for imagining and enacting radically different, sustainable, non-anthropocentric, postcapitalist futures is what we have here at hand.

Focusing on what we have here at hand offers a different way of responding to the dire challenges of now, of 'thinking the world' and enacting change - one that has been developed out of dissatisfaction with the despairing and debilitating effects of systemic theories and revolutionary programmes of change. We do not diminish the importance of identifying with greater precision what we are up against and what is lacking or problematic. But at the centre of our analysis is a reframing of the more-than-capitalist economy, what we loosely call a 'diverse economy'. And the energy that drives our scholarship is directed at bringing into being economies of ethical interdependence, what might be called 'becoming community economies'.

All of the contributing authors of this book are part of the Community Economies Research Network (CERN), a loose association of over 200 scholars around the world who are creatively engaging with the 'diverse economies approach' and are interested in thinking about the 
'what next' of economies. Inspired by the work of J.K. Gibson-Graham and (initially at least) US and Australia based members of the Community Economies Collective (see for example Community Economies Collective 2001; Community Economies Collective and Gibson 2009; http://www.communityeconomies.org [accessed 31 July 2019]), CERN's tentacles of interconnection have dispersed worldwide and the diverse economies approach has spread into many intellectual arenas. The authors of chapters in this handbook include geographers, economists, anthropologists, sociologists, business studies scholars and artists from 20 different countries. Most are involved in teaching at undergraduate and graduate level across a range of fields. In collaborating together to work on this handbook, we have reflected on the possible ways in which this handbook might be used.

One way in which we hope the book will be useful is to those working in the traditions of feminist and critical research who have long been frustrated with analysing capitalism as a monolith because such a perspective stands in the way of appreciating the promise of actually existing world-making contributions. Diverse economies scholarship offers new theorizations of livelihood and economic interconnection - of multiple trajectories of economic change that are not captured by unidimensional and unidirectional studies of economic practice and change.

A second area in which the book will be of use is in environmental studies and political ecology amongst researchers who are interested in integrating conceptions of the more-than-human as well as the more-than-capitalist into their work. Recent engagements between diverse economies thinking and ecological approaches, especially environmental humanities, have seen a shift away from a focus on human economies by diverse economies scholars. This handbook includes new thinking about the more-than-human nature of livelihood and interdependence, the work of non-humans (Earth Others) as well as humans, and the dynamics of resilience rather than growth.

A third area in which the book might be used is in the context of Indigenous struggles to gain greater legitimacy for life-affirming economic/ecological practices from which the world has so much to learn (Bargh 2012; Sepie 2017). Diverse economies research challenges the Eurocentric nature of economic theorizing that has been the subject of severe critique from the perspective of 'epistemologies of the South' (see for example de Sousa Santos 2014). Homogenizing development agendas that deploy dominant economic theory have actively de-legitimated Indigenous and folk knowledge of economic and ecological diversity (Escobar 1995). The true extent of this continued violence is increasingly coming to the fore (Kothari and Harcourt 2004). Yet livelihood practices informed by different cosmologies and collective ethics are still operating - in some contexts more strongly than others - as selected chapters in this handbook demonstrate.

A fourth use speaks to those challenging the fetishization of capitalist modernity. It is still the case that capitalist modernization dominates the global development imaginary, despite the blatant failures of this model to promote equitable and sustainable ways of living on this planet. In rapidly growing economies such as Brazil, Russia, India, Indonesia, China and South Africa (the BRIICS) the attractions of modernity and consumerism have a powerful hold on desires and individual subjectivities. To talk of a postdevelopment agenda in this context is to invite incredulity, if not derision (see Liu et al., Chapter 49 in this volume). Yet there are many in these contexts who are looking for another way forward and are interested in surmounting the subjectivity challenges to pursue a different development pathway. This 
handbook contains case material from selected BRIICS countries that shows how a diverse economies perspective might play a role in directing this path.

Finally, in many parts of the world, young people are asking what might replace our current Earth destroying systems and what role they might have in bringing that about. Some are succumbing to anxiety and depression because they see no way forward. One recent popular article interviewed Anglophone millennials who were not paying into pension funds, finding that it was not only because they do not have stable employment, but also because many believe that capitalism will have collapsed by the time they reach retirement (Spencer 2018). Others, such as millennials leading the New Zealand government have recently drawn on aspects of sustainable and inclusive 'doughnut economics' thinking (Raworth 2017) to produce a 'Well-being budget' premised on increasing well-being rather than GDP (Robertson 2018). Still others are taking matters into their own hands: members of the Extinction Rebellion Network are acting in 650 localities in 45 countries around the world to rebel non-violently against 'business as usual' in the name of human survival itself (http://www.xrebellion.org/ [accessed 31 July 2019]). For many reasons, the time is ripe to cast a spotlight on the many diverse economic activities going on around the world that also seek well-being over profit. This handbook offers many examples of action to build community economies and will be of use to millennials who are fed up with the TINA stance.

\section{THEORETICAL GROUNDINGS}

At the time of publication of The End of Capitalism (As We Knew It) in the late 1990s Marxian political economy had become mainstreamed as a mode of social analysis in many fields, such as Economic Geography. This was a remarkable turnaround from two decades prior when, under the influence of the radical social movements of the late 1960s and early 1970 s, academic researchers who sought to make their work more relevant to the problems of poverty, inequality and colonialism had turned to Marx's analysis of capitalism to explain the uneven development that was increasingly evident (Harvey 1973). Even in the late 1970s, engaging with Marxist theory identified one as a 'radical' in academic contexts. This did not stop whole cohorts of scholars from applying Marx's late nineteenth-century analysis of the capitalist accumulation dynamic and class struggle to the ways that globalization was shaping new production systems and spatial patterns of industrialization, spreading consumer cultures, changing habits, reshaping national economic policy and undermining social democratic gains. The conceptual clarity offered by a Marxian approach appealed to those who sought to pierce the veils of ideology, to dig deep to expose whose interests the status quo served, and to inform struggles for liberation and equality. Marxian analyses were elaborated and extended to understand processes of environmental degradation and ongoing uneven global development in post-colonial contexts.

But with the collapse of the socialist Soviet Union in 1991, there appeared to be no alternative to capitalism with a big $\mathrm{C}$ - even to those on the left side of politics who had agitated for its demise for decades. The ultimate hegemony of capitalism seemed to be locked in, now supported by neoliberal economic policies (embraced by policymakers and elites in many nations during the 1980s and foisted upon others through multilateral institutions such as the International Monetary Fund) in which individualism, rationality and competition are privileged and the equilibrating mechanisms of 'free' market forces are relied on to distribute 
material well-being. Those in the West who had once been committed to revolution, now opted for a larger piece of the capitalist pie, replacing their demands for radical transformation with reformist claims on wealth distribution. In the academy, critique of this new neoliberal capitalist system and its violence abounded. New research largely focused on identifying and mapping the ever changing, ever more destructive 'varieties of capitalism' - folding phenomena from all spheres of life, not only the economic, into one big narrative.

Yet the liberating appeal of Marxian analysis had been that it was premised on an intervention that placed understanding at the centre of world making. Karl Marx's famous adage from his 1845 writing was inscribed on his grave. It reads: 'Philosophers have hitherto only interpreted the world in various ways; the point is to change it'. Marx advocated that scholars and strategists should seek to understand the world in order to change it. Indeed, the measure of success of any intellectual endeavour is the change that it provokes and enables. But by the early 1990s it seemed that no matter how much radical interpretation there was of capitalist crisis and restructuring, it was not generating strategies aimed at major socio-economic transformation, instead it was capitulating to the ever-inventive power of capital.

It was in this context that Gibson-Graham proposed to abandon the study of a capitalist system (an '-ism' with essentially immutable laws) and move to the study of capitalist economic practices, as well as other kinds of economic practices. The emphasis on practices focused in particular on the capitalist class process - the distinctive mode of producing, appropriating and distributing surplus labour (realized in the market as surplus value) that arose with the rise of waged employment involved in generalized commodity production in the context of private capitalist firms (Resnick and Wolff 1986). This decision to refocus on practices was a refusal on a number of accounts. One, it was a refusal of economic determinism and the ontological commitment to certain economic processes (such as capitalist accumulation) as more determining of world outcomes than others. Second, it was a refusal of empirical realism and the epistemological commitment to a simple separation between reality and reflection that could be directly mediated by neutral empirical evidence. Gibson-Graham began to conceptualize a world of overdetermination in which all existing conditions are the outcome of their myriad conditions of existence. Here they were influenced by Stephen Resnick and Richard Wolff's anti-essentialist analysis of class as a process, itself an operationalization of Louis Althusser's concept of overdetermination (Resnick and Wolff 1986, 1987; see also Madra 2006). In an overdetermined world, knowers accept both the indeterminacy of all knowledge and that knowledge making itself has powerful effects. They need to employ a way of knowing (an epistemology) that is suitably non-hubristic and unpretentious, taking steps, for instance, to be transparent about their entry point from which they trace connections and make meaning in the entangled mess of the world.

In this modest way of knowing, we use capitalist as an adjective that describes a particular version of a practice. Researchers are compelled to unpick the practices and enactments usually conflated or aligned, and are encouraged to ask what is capitalist about this or that. Of course, what is referred to as capitalism does not just disappear when this move is made. But what is revealed are the effects of our representation when it is totalizing, that is, combining diversity into a coherent, homogeneous whole, and when it is essentializing, that is, promoting a capitalist economic essence that ignores, devalues or conceals diversity. Researchers can thus refuse to totalize or essentialize, and instead attempt to stand back and assess whether the effects of our representations are opening up spaces for change and transformation or not. Refusing a conception of 'capitalism' is a discursive move, focused on representation and 
language, yet it also has material effects in terms of helping to imagine and enact 'more than capitalist' economies.

Importantly, Gibson-Graham, along with many other social and feminist theorists at the time, began to pay attention to the way that research is performative, that is, it brings into being that which it theorizes. Research makes some things 'more real' by the very act of focusing on certain objects or relations, by developing language with which to identify and distinguish these objects or relations, and by devising discursive framings that situate these objects and relations in hierarchies of meaning. Research can have the effect of demarcating what is reasonable, possible, legitimate and modern. The performative act of theorizing and researching has the potential to move from the symbolic realm of language and discourse into the material realm of affordances and embodied action - creating states of being, shaping subjectivities and directing experiences. Such a conception of knowledge production acts as a salutary warning to researchers to consciously examine what effects (objects, relations) they are participating in making 'more real'. At the same time, it is an invitation to upturn and yet still build on Marx's adage that we understand the world in order to change it. As Gibson-Graham (2008) once put it - changing our understanding of the world is to change the world (if only partially and locally). By participating in the act of discourse creation, we are actively inviting shifts in bodily being and subjectivity.

As diverse economies thinking has matured and new scholars have joined in the conversation, other theoretical interventions and political concerns have influenced its development. Some of these scholars have challenged the false separation of economic and ecological thinking and the privileged status of the human subject in Western thought (Miller 2019). Diverse economies scholars have welcomed engagements with ecological humanities, political ecology and science and technology studies and these have stimulated new formulations (see, for example, the collection edited by Gibson et al. 2015). While one of the inspirations for theorizing economic diversity came from ecological thinking, in which diversity is seen as a key contributor to resilience, new work is exploring greater connections between ecological dynamics and the dynamics of community economies that might be activated by ethical intervention (Barron 2015; Gibson et al. 2010; Gibson-Graham et al. 2016). Assemblage theory and material semiotics has greatly informed new thinking about how change occurs - extending the conception of who and what acts (St. Martin et al. 2015 and the framing chapter on subjectivity by Healy, Özselçuk and Madra, Chapter 43 in this volume). At the centre of these new developments is the more-than-human subject - a reconceived agent of a very different kind of decentred and distributed politics (Miller 2019; Roelvink and Zolkos 2015). As can be seen by this brief intellectual genealogy, the theoretical groundings of diverse economies research are understood to be perpetually evolving as new thinking and political concerns challenge previous formulations.

The performative view of theory and research opens up the possibility of making worlds, but it offers no easy recipe for social transformation (Cameron et al. 2011). The work of knowledge production in the service of making other worlds possible must harness and deploy many different strategies in order to pull against the mainstream. In the diverse economies research programme, we have drawn on and developed a suite of 'thinking strategies' to help this effort. 


\section{CRITICAL THINKING STRATEGIES}

Diverse economies scholarship proposes a reframing of the economy. Reframing involves first, the work of critique to disempower the framing that is standing in the way of change, and second, the work of building a new framing that can enable different kinds of action. This section briefly introduces critical thinking strategies that challenge the framing of capitalism as the ultimate real, as something we can't imagine the world without, as the inevitable container and constrainer of possibility that operates outside of society. The next section elaborates how inventory is utilized to produce a new framing of economy.

Capitalocentrism is a term that was coined by Gibson-Graham to describe the way a set of economic practices and relationships ascribed to capitalism are established as the dominant, most efficient, modern, innovative and dynamic forms of economic activity that have hitherto existed. The specific practices that are foregrounded in capitalocentric representations are waged labour, commodity production, private enterprise, private property and institutional finance. The dynamics that are privileged are those of supply and demand and capital accumulation motivated by competitive rational self-interest. Against this self-reinforcing constellation of practices and dynamics other forms of economic activity are deemed subordinate, inefficient, pre- or non-modern, static or stagnant. One effect of capitalocentrism is thus to situate all other ways of labouring, transacting, enterprising, owning and allocating investment in a subordinate, complementary, oppositional, or outsider relationship to capitalism. Another is the conflation effect whereby the appearance of commodity markets or paid labour is read as an indication of the presence of capitalism and not as an empirical observation whose connections to other phenomena need to be traced and theorized. Capitalocentrism is associated with a kind of strong theory that knows where power lies, that suspects how phenomena line up to consolidate power and that cannot be surprised. Research conducted in this mode appears to be bold and innovative because it quickly identifies the new, but merely rolls out cookie cutter analysis folding the new into a familiar embrace.

The critical work of identifying capitalocentrism is a task in itself. Challenging capitalocentrism is not easy. This is because capitalocentrism invades so much thinking that it has become normalized. It is now 'common sense' to think that getting a paid job is the only way to survive, or that capitalist growth benefits all, or that eliminating any barriers to the free movement of traded goods is for the greater good, or that big banks and other financial institutions are best equipped to manage our investments. It is increasingly difficult to think otherwise, and yet as the chapters of this handbook demonstrate, there is a rich world of economic difference out there to learn from.

Deconstruction is a technique that helps to identify how power is distributed by meaning making into a binary structure based on opposition and exclusion (A/not A) (Derrida 1967). It exposes how, in the Western philosophical tradition, meaning is constructed around presence and essence to the exclusion of absence and difference (Derrida 1967; Gibson-Graham 2000; Laclau and Mouffe 1985). In economic theorizing the dominant term 'capitalist' is associated with a train of linked concepts - capitalist business and private accumulation, waged and salaried labour, commodity production and exchange in markets, private property, especially privately owned means of production, and interest-bearing finance. Each of these concepts is in turn defined by what it is not - that is, its outside. Chains of association link these dominant terms building up the representation of a powerful, coherent, dynamic whole against which any constellation of 'outsides' cannot stand up with the same power, coherence and dyna- 
mism. Yet deconstruction reveals that each dominant term cannot be comprehended without its opposite. Thus markets in which goods and services are quickly and 'freely' exchanged in transactions with finite ends can only be understood by reference to gift transactions that bind the givers and receivers into lengthy time-spanning relations of obligation. The presence of the dominant term is only ever constructed out of its inherent dependence on its other. The deconstructive move reveals the moments of contradiction and undecidability, that is, the multiple failures that allow the outsides to destabilize meaning making (Ruccio 1998). This move thus clears the way for a form of weak theory that is able to describe, appreciate, connect and analyse, identifying strengths to build on and constraints to work around.

The diverse economies intervention mobilizes weak theory to achieve a mighty effect - the destabilization of capitalist hegemony. The primary 'weapon of destruction' is thick descriptive inventory that breaks down the powerful presence of any dominant term, showing how it contains difference. Inventory makes both sides of the binary multiple. Drawing on the contaminations that deconstruction points to, weak theory can then make its advances - challenging capitalocentrism, queering alignments and opening up the potential for making new alliances. ${ }^{11}$ What results is a prolific and detailed heterogeneity. When applied to capitalism this produces the fecund landscape of diverse economies where the range of what can be imagined and what is possible is considerably widened (Hirschman 2013).

\section{INVENTORY AS A STRATEGY FOR OPENING UP 'THE ECONOMY'}

Diverse economies scholarship focuses on both the heterogeneity of economic practices and the unfixed nature of the alignments and connections between them. The iceberg has emerged as a powerful tool for communicating the idea of a diverse economy (Figure 1.1) 12 Above the waterline we see the economic practices that are associated with the capitalist economy waged labour, production of commodities for exchange in markets, in capitalist businesses. Below the waterline we see a host of heterogeneous practices - some of them explicitly 'economic' (such as barter, in-kind payment or cooperatives), others more social (such as child and elder care, activities in churches or temples or schools) and others decidedly ecological (such as photosynthesis, soil formation or fungal growth). Versions of this image have been used in countless conversations with different constituencies. Its effects are multiple. One is to make 'the economy' suddenly something different than what gets reported on in the nightly news. It is expanded and opened up to its outside - to the 'others' who also contribute to maintaining livelihoods alongside, and in many cases, supporting those who earn wages, trade commodities and generate new wealth. This in turn promotes another effect - a subjectivity shift for those who usually see themselves as marginalized or excluded from the 'real' economy above the waterline. The iceberg image positions them as economically active and possibly able to engage in discussions about how economic futures might be shaped. When the iceberg economy is collectively produced it can also illustrate the gender division of labour and prompt discussions about how different kinds of activities are valued or devalued. This representation thus provokes ethical reflection and prepares the ground for discussion about what kinds of economic activities could be strengthened and how.

While the iceberg image is useful in practical settings, a more systematic framing of the diverse economy has been developed for use in research. This framing relies on an inventory 


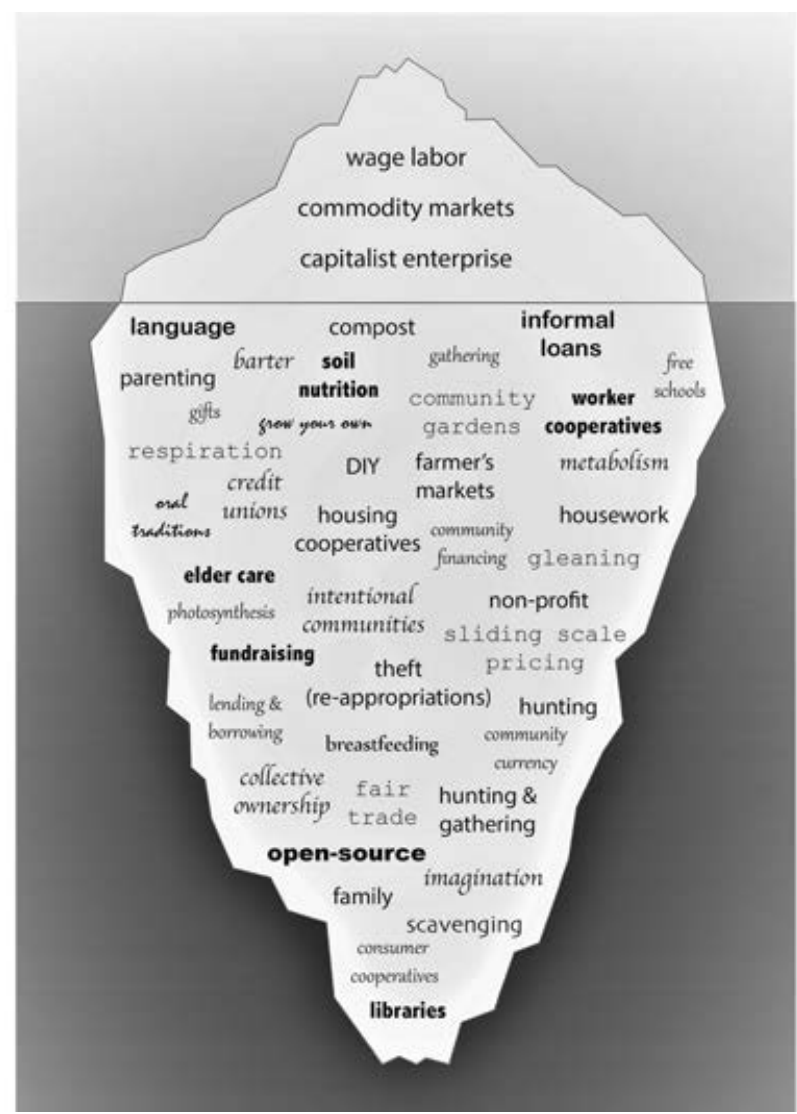

Source: Drawn by the Community Economies Collective. This image is licensed under a Creative Commons Attribution-ShareAlike 4.0 International License.

\section{Figure 1.1 The diverse economies iceberg}

of economic activities drawn from a range of sources - including established research in various disciplines and ongoing field work. An inventory is usually a complete list of terms - but the inventorying associated with the diverse economy research programme is never complete and does not aspire to total coverage (as would be expected when operating from the stance on ontology and epistemology laid out above). Its main purpose is to challenge the de-legitimation of certain economic knowledges, working therefore to bring into question practices and discourses which homogenize dominant economic knowledges. The inventory employs a loose classificatory framing that broadly defines 'types' of economic activity. ${ }^{13}$ It acts as a provocation to 'take back the economy' - populating it with what is at hand and valuing the productivity of many kinds of economic endeavours.

Economic activities in the diverse economies analytical framework are arranged into five 'types' relating to enterprise, labour, transactions, property and finance. The first five sections of the handbook are organized around these activities. Each type of activity relates to 


\section{Table 1.1 Enterprise diversity}

\begin{tabular}{ll}
\hline ENTERPRISE & Appropriators of surplus \\
\hline Non-capitalist & \\
Communal or worker-owned cooperative & Cooperators \\
Independent or Sole proprietorship & Self \\
Feudal estate & Landlord/household head \\
Slave enterprise & Slave owner/leaser \\
Capitalist & \\
Family firm & Family \\
Private unincorporated firm & Business owners \\
Public company & Board of directors \\
Multinational & Board of directors \\
More than capitalist & \\
State capitalist enterprise & State authority \\
Green capitalist firm & Board of directors \\
Socially responsible capitalist firm & Board of directors \\
Non-profit enterprise & Board of directors \\
Social enterprise & Board of directors and community stakeholders \\
Producer and consumer cooperatives & Producers, consumers \\
Tribal enterprise & Registered members \\
\hline
\end{tabular}

a form of economic process or transaction. Within each type, diversity is inventoried in such a way as to highlight certain social relations that also distinguish each type of practice.

\section{Enterprise}

Enterprise (also known as business or the firm) is usually seen as the locus of economic activity associated with production and profit making. It is the primary organizational context in which new wealth generation occurs and production, appropriation and distribution of surplus take place (see the framing chapter by Cameron, Chapter 2 in this volume). In the diverse economies framing enterprise is differentiated according to the type of class process (including capitalist, feudal, slave, communal and independent) that characterizes production relations. The class process involves the production of both the means of survival (payments to workers) and surplus generation (new wealth) that takes place within enterprises, which themselves take various forms, such as companies, corporations, cooperatives, firms, businesses, households, farms or estates. It also, importantly, involves the appropriation and distribution of surplus by different agents and this is what distinguishes different kinds of enterprises in a diverse economies framing. Table 1.1 shows a range of enterprise types and identifies who appropriates surplus and thus makes decisions about its distribution.

The organizational details of each enterprise type are the subject of much study in the fields of economic history, economic sociology, economic geography, organization studies and business studies among others. In these disciplinary contexts the focus of attention may rest on many other aspects of the enterprise than that of its class process. Why the diverse economies approach highlights this one dimension (its entry point, if you like, into enterprise analysis) is because it helps to focus attention on the ends to which surplus (i.e. wealth) distribution are put. In non-capitalist enterprises surplus flows to a wide range of ends from worker-owners themselves in worker-owned cooperatives and sole proprietorships, to feudal patriarchs or 
slave owners. In the 'more than capitalist' firms that may have many attributes of mainstream business, what surplus there is left over from distributed payments to all the claimants on surplus is deployed to a range of ends, not only private accumulation. This could include to 'other' ends, such as the national commonwealth, the environment, a social grouping that may be marginalized, registered members of a tribe, or a constituency of stakeholder producers or consumers. The assumption usually made is that all capitalist firms distribute appropriated surplus to the private accumulation funds of owners and CEOs. While this is undoubtedly the case for many firms, some (more than) capitalist firms incorporate into their business model distributions to genuine environmental stewardship or community resilience. The diverse economy researcher approaches any assumptions about business practice with a questioning mind and empirical curiosity (see Cameron, Chapter 2 in this volume).

\section{Labour}

Labour is at the centre of making and providing livings. It involves expenditure of energy in the production of goods and services - from child minding, to steel making, opera singing, programming, cooking and making honey (see the framing chapter by McKinnon, Chapter 12 in this volume). The diverse economies framing has been heavily influenced by feminist thinkers who have drawn attention to the immensity of unpaid labour performed by women in all economies. More recently, the work of Earth Others has been acknowledged. The entry point for distinguishing different types of labour is the form of remuneration or compensation (monetary and non-monetary) they receive. For some labour, remuneration is directly tied to securing material survival needs and variation in the amount of remuneration dramatically affects the kind of livelihood that can be supported. Other forms of labour are unremunerated in monetary terms, but receive compensation in other forms, for example, love, enjoyment, connection or habitat protection. Table 1.2 shows a range of types of labour and identifies the related form of remuneration in each case.

As this table shows, many important forms of labour are unpaid or unremunerated, and only some labour is remunerated with monetary wages or salary - yet this 'paid work' occupies the attention of most labour analysts such as labour economists and geographers, sociologists of work, industrial relations, productivity and labour process experts. Certainly the rise of precarious work (here represented by non-unionized, part time, temporary and seasonal labour) is a serious concern. Precarious labour is unprotected by regulations or union agreements and monetary remuneration is not sufficient to meeting material survival needs (see Chapter 13 by Pavlovskaya in this volume). So too is the continued prevalence of slave labour conducted under conditions of unfreedom. But alongside these less desirable forms of labour are a plethora of forms of labour that are 'remunerated' in other ways via a range of monetized and non-monetized transactions reflecting a multitude of relationships. These should not be ignored. The effect of open inventorying is to bring to light all the kinds of labour working to sustain life on Earth alongside all those that are not life-sustaining or just, in order to guide actions that promote the ethical negotiation of greater parity and sustainability of labouring. 
Table $1.2 \quad$ Labour diversity

\begin{tabular}{|c|c|}
\hline LABOUR & Form of remuneration \\
\hline \multicolumn{2}{|l|}{ Unpaid } \\
\hline Earth Others & Non-monetary or none \\
\hline Housework & Non-monetary or none \\
\hline Family care & Non-monetary or none \\
\hline Emotional labour & Non-monetary or none \\
\hline Neighbourhood work & Non-monetary or none \\
\hline Volunteering & Non-monetary or none \\
\hline Slave labour & Food and lodging \\
\hline \multicolumn{2}{|l|}{ Waged } \\
\hline Salaried & Negotiated salary + benefits \\
\hline Unionized & Protected wage + benefits \\
\hline Non-unionized & Unprotected wage \\
\hline Part time & Un/protected wage \\
\hline Temporary & Unprotected wage \\
\hline Seasonal & Unprotected wage \\
\hline Familial & Personally set wage \\
\hline \multicolumn{2}{|l|}{ Otherly remunerated } \\
\hline Self-employed labour & Living expenses + savings \\
\hline Self-provisioning labour & Food and other goods \\
\hline Cooperative labour & Cooperative wage + share \\
\hline Indentured labour & Food, lodging and stipend \\
\hline Feudal labour & A portion of the harvest \\
\hline Reciprocal labour & Reciprocated labour \\
\hline Bartered labour & In-kind payment \\
\hline Work for welfare & Dole payment \\
\hline Intern labour & Job experience + stipend \\
\hline
\end{tabular}

\section{Transactions}

Transactions are at the heart of all economic relationships - they are what connect economic units: be they individuals, communities, regions or nations. Transactions are encounters where ethics, values, trust and certainty play out in a diversity of ways (see framing chapter by Diprose, Chapter 21 in this volume). They include equal and unequal exchanges, but also sharing, allocating, reciprocating, authorized taking and stealing. Mainstream economic theorizing is primarily concerned with market transactions involving commodity exchange in which pricing mechanisms determine the commensuration of flows between buyer and seller. The idea of a 'free market' supported by freedom of information, freedom of movement and freedom from state intervention is a guiding ideology. But many crucial transactions take place in markets that are decidedly not free - pricing is influenced by monopoly control or protection and yet is represented as economically efficient. In 'other market' transactions so-called 'free' market mechanisms are held at arm's length and there is recognition that calculations of commensurability are governed by social agreement. Even more transactions take place outside of any form of calculability where the 'rules' of encounter are negotiated but not necessarily around commensurability as shown in Table 1.3. 
Table 1.3 Transactions diversity

\begin{tabular}{|c|c|}
\hline TRANSACTIONS & Rules of encounter \\
\hline Non-market & Incommensurability \\
\hline Household flows & Intra-household negotiation \\
\hline Gift giving & Cultural norms of reciprocity \\
\hline Indigenous ritual exchange & Gift rituals \\
\hline Gleaning & Traditional right \\
\hline Hunting, fishing, foraging & Negotiation of stewardship \\
\hline Theft & Illegal right \\
\hline Poaching & Right of the have-not \\
\hline Earth Other exchanges & Habitat maintenance \\
\hline State allocations & Citizen entitlements \\
\hline State appropriations & State entitlements \\
\hline Market exchange & Economic commensurability \\
\hline 'Free' & 'Laws' of supply and demand \\
\hline Naturally protected & 'Natural Law' \\
\hline Artificially protected & Social agreements or state policy \\
\hline Monopolized & Monopoly corporate power \\
\hline Regulated & State policy \\
\hline Niche & Social agreement \\
\hline Other market & Social commensurability \\
\hline Sale of public goods & State policy \\
\hline Ethical 'fair trade' markets & Producer-consumer agreement \\
\hline Local trading systems & Producer-consumer agreement \\
\hline Alternative currencies & Community agreement \\
\hline Underground market & Trader agreement \\
\hline Co-op exchange & Inter-co-op agreement \\
\hline Barter & Trader agreement \\
\hline Informal market & Trader agreement \\
\hline
\end{tabular}

Non-market transactions such as gift giving, household flows, Indigenous, ritual and reciprocal exchange are studied by economic anthropologists and economic historians but they are often represented as remnants of past practices, or only present in 'out of the way places', or as forms of corruption. Other non-market transactions involving the state are studied by scholars of government and the public sector and are often seen as external to the productive economy (but see Mazzucato 2011). The diverse economies framing includes all these transactions as contemporary components of operating economies and identifies the myriad 'rules' by which these encounters are managed. As with labour, the inventory includes both wanted and unwanted practices. Certainly all forms of commensurability are not equal or equally desirable. By identifying the diversity of negotiations and power struggles that shape transactional encounters it is possible to locate opportunities for oppressive relations to be solidified or something different to emerge, including economic relations more deeply grounded in justice and sustainability. It may be that rather than lying only in the past, these forms of relational transactions and reciprocity are exactly what will sustain us in times of financial and ecological crisis. 


\section{Property}

Property is commonly understood as a concrete material object that can be owned, for example a house, land, a machine or a car. Increasingly, however, property is also being thought of as something immaterial, like a patent or computer code, that can still be owned. In the diverse economy framing property is seen as a relation between people with respect to things both material and immaterial (see the framing chapter by St. Martin, Chapter 30 in this volume). The entry point into distinguishing different types of property is the framework (legal or illegal) by which access to property, and to the benefit it provides, is regulated. Table 1.4 shows some of the diverse types of property with their associated forms of regulation.

The inclusion of property in the diverse economy framing is a relatively new development and one that will be enhanced by further collaboration with legal scholars and Indigenous scholars (see Chapter 36 by Morgan and Kuch in this volume; see also Bargh 2012).

\section{Table $1.4 \quad$ Property diversity}

\begin{tabular}{ll}
\hline PROPERTY & Regulating access \\
\hline Open access & None \\
Atmosphere & Freedom of the seas doctrine \\
Oceans beyond national zones & None \\
Open source intellectual property & \\
Privately owned & Private property rights \\
Private individual & Private property rights of stockholders \\
Private corporate & Doctrine of tenure and estates \\
Feudal & Piracy, theft, confiscation, occupation \\
Stolen & \\
Collectively 'owned' & Ancestral rights, treaties \\
Indigenous land, rivers, sea & Cooperative law \\
Collective property & Public statute \\
State managed assets & Rules of commoning \\
Common property &
\end{tabular}

\section{Finance}

Finance is an increasingly dominant sector of the global economy that impacts on the livelihoods of citizens around the globe. The financialization of the economy and of everyday life is one of the most powerful, dangerous, and detrimental outcomes of the neoliberal revolution (see discussions in Epstein 2005). Contagious financial crises associated with this financialization fostered by neoliberalism have had disastrous effects on the living standards and life chances of vulnerable groups. The 1990s began a period of severe and cross-nationally contagious financial instability. Among the most notable and severe of these crises were the Mexican financial crisis of 1994-5 and the East Asian financial crisis of 1997-8. Then came the global crisis of 2007-8.

From a diverse economies perspective it is important to constrain and reduce the power of the financial sector, to place finance in the service of the economy (especially what macroeconomists refer to as the 'real economy'), and to maximize the potential of finance to support emancipatory, ethical and solidaristic diverse economic practices (Gibson-Graham 1996, 


\section{Table $1.5 \quad$ Finance diversity}

\begin{tabular}{|c|c|}
\hline FINANCE & Return \\
\hline \multicolumn{2}{|l|}{ Non-market } \\
\hline Sweat equity & Increase in asset value \\
\hline Crowd-sourced funding & Recognition \\
\hline Family lending & Intergenerational support \\
\hline Migrant remittances & Family claims \\
\hline Rotating credit and savings associations & Negotiated by group \\
\hline Donations & None or tax deduction \\
\hline Interest-free loans & None \\
\hline Treaty finance & State compensation \\
\hline Debt bondage & Enslavement \\
\hline Bribery & Favours \\
\hline Patronage & Negotiated repayments + loyalty \\
\hline \multicolumn{2}{|l|}{ Market } \\
\hline Retail banks & Market set interest on mortgages and personal loans \\
\hline Commercial banks & Market set interest on business loans \\
\hline Investment banks & Market set interest on mega-loans \\
\hline Insurance companies & Premiums based on statistical risk \\
\hline Other financial institutions & Market set interest on loans \\
\hline \multicolumn{2}{|l|}{ Other market } \\
\hline State banks & Government set interest \\
\hline Islamic banks and financial instruments & Qur'ranic code \\
\hline Credit unions & Below market interest to benefit member owners \\
\hline Cooperative banks & Negotiated by cooperative members \\
\hline Community currencies & Negotiated by community members \\
\hline Payday lending & Dictated by the lender, backed up by extortion \\
\hline
\end{tabular}

Chapter 6; Grabel 2017). The diverse economies framework prompts identification of the many ways that people interact with finance, for example, how and when they save and invest, how and under what social relations they borrow and lend, and the different ways that financial returns are negotiated, distributed and contested (see the framing chapter by Safri and Madra, Chapter 37 in this volume).

Most analysis of finance in the fields of business studies, accounting and international finance is focused on what we might think of as a Wall Street (or what we might call a mainstream) narrative of finance in which finance comprises the world's major investment and commercial banks, stock and bond markets, private equity funds, derivatives, collateralized debt obligations, and other types of exotic, opaque and volatile financial instruments. Yet as Table 1.5 shows, there are many ways that economic subjects access finance outside of this Wall Street view of finance. Non-market finance is accessed through face-to-face or direct negotiation where the return takes a non-monetary form or, if it is monetized, does not represent an increased return. Finance provided by 'other market' forms is paid back in monetary form but according to a range of non-market related considerations. It is an empirical question as to which kinds of finance are more resilient and emancipatory. Certainly there are many coercive and illegal forms of financing that are still prevalent today and, indeed, as shown by the forensic analysis of the 2007-8 crisis, some of these are active within the mainstream finance sector. The diverse economies inventory of finance provides insight into where solidarity can be built to ensure investment in resilient futures is being made. 
To conclude this discussion, it is important to reiterate that the purpose of this representation of economic heterogeneity is to undermine the power of a capitalocentric world view. As diverse economic practices are proliferated and named, it becomes clear that capitalocentrism is an overwhelmingly neocolonial approach to thinking about the world, one which erases the diverse epistemological, ontological and even cosmological standpoints of peoples everywhere. As Boaventura de Sousa Santos writes, 'such diversity should be valorized' because 'the understanding of the world far exceeds the Western understanding of the world', and social justice is impossible without what he calls 'cognitive justice' - that is, the recognition that 'emancipatory transformations in the world may follow grammars and scripts other than those developed by Western-centric critical theory' (2014, p. viii). In what Arturo Escobar (2018) calls this pluriverse, different practices and different rationalities of enterprise, labour, exchange, relationships to things and land, and ways of investing in the future coexist in multiple 'ecologies of productivity' (de Sousa Santos 2014). Inventorying diverse economies performs this pluriverse of potential productivity in ever more visible and material ways.

\section{POWER, SCALE AND UN/DESIRABILITY}

The diverse economy framing as elaborated above is an intervention that opens up the economic landscape, and the mind, to many different projects. This approach prompts researchers to question what they are investing in when they opt to study one or other aspect of this diversity. In this sense the framing is a politico-ethical intervention. It opens up a space of indecision that must be filled by action. The performative research actions taken by diverse economies scholars have often been questioned by those concerned about: power and the dangers of co-optation; scale and the potential ineffectiveness of 'small-scale and often intimate practices of alternative or diverse economies' (Leyshon 2010); and the undesirable and unwanted diverse economy. In this section these concerns are addressed.

One way the diverse economies framing challenges power is by tackling capitalocentric representations and exposing their effects. Beyond that, the framing makes no claims about how power is distributed in the economy. What it does do is enlarge the scope for explorations of how power is enacted. The tables above distinguish types of economic activity according to certain processes of negotiation - all of which cannot be known ahead of their practice. It is through the actual negotiation - constrained as it might be by institutions, laws, alliances, technologies, natures and so on - that power is enacted. Whether it is power over, power with, or power to, this power is not a pre-distributed stock permanently held in place by one agent, but is fluid (see Chapter 45 by Gabriel and Sarmiento in this volume).

The language of economic diversity can be an aid in understanding what is often represented as the 'power of capital'. For example, the inordinate influence of financial institutions in governing daily life might be usefully unpacked by reference to the ways that bribery, patronage, gift giving, state allocations, underground trader agreements and patronage figure in the operations and crises of financial markets. Rather than assume that an assemblage is inherently capitalist and thus powerful, the diverse economies approach uses weak theory to expose the workings of power - including its strengths and fragilities. In a similar vein, empirical curiosity and a resistance to theoretical closure informs the response to critics who are concerned that any experiment with intentional economic activities directed towards economic justice or ecological sustainability will suffer the fate of 'co-optation' by capital or the state. The 
diverse economies approach has been specifically developed to avoid reliance on essentialist arguments of inevitability and the unidirectionality of change. This approach provokes inquiry with an open mind - one that avoids the simplified short-termism of coarse-grained judgements regarding the 'success' or 'failure' of economic experimentation. Indeed, it challenges researchers to consider the role their research plays in strengthening certain understandings of power and co-optation.

Questions of scale are usually another way of broaching power (Gibson-Graham 2002). The economic practices described in this inventory are not present in every sector of the economy or every place in the globe - again it is an empirical question as to which of these (or other as yet unspecified) diverse economic activities are operating in any one context. But many of the non-capitalist practices that might be thought of as 'local' are ubiquitous and in this sense are 'global'. For example, the practices of care labour, housework, family lending, migrant remittances, household flows of goods and services are everywhere - they are global and local - and together they exert inordinate power over population dynamics, one of the most important determinants of liveability on this planet (Safri and Graham 2010). Similarly, the work of (and exchanges between) Earth Others take place in ecologies and atmospheres the world over. The incredible power that these place-based and Earth system-contributing activities have to construct a thin membrane of liveability for all living species is only now being understood, just as it is being threatened by the actions of humans (Latour 2014).

It would be ridiculous to ask whether the powerful work of households and Earth Others could be 'scaled up' for greater effect. Yet this question is often asked of diverse economies scholars who research intentional ethical economic practices in diverse economies the world over. Behind this question is a nested conception of scale and a distributed hierarchy of power: the local is small and less powerful - the global is large and more powerful (Cameron and Hicks 2014; Marston et al. 2005). This concern will be revisited in the context of the discussion to come on building community economies.

Inventorying diverse economies reveals undesirable and unwanted practices, where coercive power, inequality and environmental destruction are played out. To bring these economic practices to visibility is not to condone them, nor is it to neutralize them. Many such practices are conducted by capitalist enterprises, but they are clearly also part of the operations of non-capitalist enterprises and practices. It is as important to recognize, for example, the extent of the involvement of modern-day slavery in global capitalist supply chains, and actions to expose and eradicate it, ${ }^{10}$ as it is to identify the extent of cooperativism and practices of mutuality and actions to support them. Studying diverse economic practices is not only for finding possibilities, but also for ruling out possibilities, for laying out other projects of transformation. All economic practices and the subjects who perform them can be involved in change. For example, the meagre remuneration paid to indentured migrant domestic helpers may become an investment stream that funds community enterprise in their home countries (Gibson et al. 2001). And the appropriation of rotating credit associations by the state to control narratives of womanhood, as in Indonesia (Niehof 1998), is not to deny the empowerment these schemes offer women in other parts of the world (see Chapter 39 by Hossein in this volume). The diverse economy framework is thus a good tool for working against certain practices, although much scholarship has so far been dedicated to working for others.

The aim of inventorying economic diversity in an anti-essentialist framing is to 'affirm that lives unfold in a "pluriverse" rather than a "universe"" (Gibson-Graham et al. 2017). Within this pluriverse, diverse economies researchers are interested in devising pathways towards 
more sustainable and equitable worlds, ones that recognize and attempt to avoid being enrolled in the dominant capitalist pathway of growing inequality and environmental degradation. This involves a positive project of strengthening and creating those diverse economic practices that have the potential to support ethically oriented community economies. In the last section of this introduction we clarify an important distinction (sometimes lost on critics and collaborators alike) between conducting a diverse economies inventory and imagining and enacting community economies.

\section{REFOCUSING ON ETHICAL ACTION}

Representing the economic landscape as heterogeneous is an ethical intervention that has the effect of reducing the discursive dominance of capitalism and opening up the space of possibility in an economic pluriverse. But this is not the endpoint of analysis. Diverse economies scholars are committed to describing, theorizing and inventorying a range of ethical economic actions that enable more-than-human flourishing and those that stand in its way. 'Community economies' is the shorthand term used to denote the complex interdependence of such actions (Gibson-Graham 2006). The term 'community' is used here to imply the hard and joyful negotiation of 'being in common' (Nancy 1991). Community is never set and stable, it is not pre-given nor can it be assumed to be homogeneous. Community is always in the process of becoming, especially through negotiation. This handbook contains many chapters that address different ethical actions that are building community economies.

In Take Back the Economy: An Ethical Guide for Transforming Our Communities, Gibson-Graham, Cameron and Healy (2013) make the case for transformative action based on negotiations around six key areas of shared concern - which broadly map onto the diverse types of economic activity already discussed. These concerns, or coordinates, are framed as open questions that loosely relate to the entry points used to differentiate diverse practices.

- For enterprise, the concern is wealth distribution and the question is: How can surplus be produced, appropriated and distributed so as to enhance human and planetary well-being?

- For labour, the concern is livelihood well-being and the question is: How can different forms of work and remuneration be combined so that humans and Earth Others survive well?

- For transactions, the concern is with ethically responsible encounters and the question is: How can human-human and human-Earth Other encounters enhance well-being for all?

- For property, the concern is with access to the benefit of property and the question is: How do communities make and share commons?

- For finance, the concern is present and future security and the question is: How does investment provide us with returns that protect against risk now and into the future?

Underpinning all these is a fundamental concern for sustainable consumption and the economic subject. Here the question is: How do consumer subjects become subjects of sustainable community economies?

The topic chapters of this handbook showcase creative research around these questions and concerns. Some chapters document new experimentation that is place-based, others discuss interventions in state and international agendas. All are based on new empirical and theoretical research. The cumulative contribution of these chapters constitutes a powerful programme of action towards building other possible worlds. The community economy is revealed here and 
now in its specificity as a 'macro actor' that works in and through multiple sites and transnational networks to transform places, sectors and subjects.

It is not yet two decades on from the millennial World Social Forums that shook the world and provoked a widespread awakening to the fact that another world was not only possible but desperately needed. In the intervening years diverse economies researchers have explored the 'seemingly insignificant nooks and crannies of everyday business and domestic life' (Leyshon 2010 , p. 122) theorizing other-than-capitalist practices that might be harnessed to produce something else, something more-than-capitalist. It is these glimmers that community economies research attempts to string together into larger constellations of possibility (Morrow and Dombroski 2015). In doing so, diverse economy scholars 'cultivate a politics of horizontal extent, reach, and association rather than a "politics of scale"" (St. Martin et al. 2015, p. 16).

We take inspiration here from the activism that women and Indigenous peoples of the world have undertaken, and we place some of our hopes on the numerous movements the young people of the world are engaging in. In these movements the scale of action is never anything less than global. Because women are everywhere and therefore always somewhere, change can be enacted in all those many somewheres (Dombroski 2016; Gibson-Graham 2005). And because of the ubiquity of Indigenous struggles, local place-based activism is also everywhere. Because young people are increasingly interconnected with each other and questioning the 'way things are', we have hope that in the same way, change-making practices can travel and spread, scaling out (rather than up) through relational networks and associations. There is no expectation that change will look exactly the same everywhere. Indeed, there is no sense in dictating or designing one grand action strategy, because that impulse is where many of the world's problems might be traced to - forms of imperialism embedded in a Eurocentric understanding of the world requiring abstraction and universalism (Escobar 2018). What we can do is adopt shared thinking strategies that activate hopeful inquiry (Hirschman 1971), to refuse to crush the activism of the hopeful with academic critique that only lines things up and closes off options for transformative action. We hope that this handbook will contribute to mobilizing global community economies building collective power via extensive meshworks linking multiple gatherings of diverse liberatory economic practice. ${ }^{17}$

\section{NOTES}

1. J.K. Gibson-Graham is the joint authorial subject shared by feminist economic geographers Katherine Gibson and the late Julie Graham. J.K. Gibson-Graham was conceived in 1992 and born in published form in 1993 after more than a decade of co-writing under separate names. Since the death of Julie in 2010, J.K. Gibson-Graham has continued to publish both alone and in collaboration with others.

2. In this handbook authors use 'diverse economy' and 'diverse economies' interchangeably. In an emerging field such as this, terminology is still being worked out. Originally the focus on diverse economic practices in a falsely named 'capitalist economy' led to the concept of 'a diverse (not only, or more than, capitalist) economy'. As thinking has developed in relation to what 'an economy' is, there has been a greater resort to use of the plural 'diverse economies'.

3. How this class process was supported and enabled by other practices associated with capitalist development, such as formation of the joint stock firm as a legal entity, the rise of mechanization and fossil fuel production, the formation of capitalist business associations and trade unions and so on, is, in this approach, a question for historical analysis not theoretical assumption.

7. The term 'overdetermination' was taken from Sigmund Freud's dream analysis and used by the Marxist philosopher Louis Althusser to describe this anti-essentialist approach to ontology. Resnick 
and Wolff (1987) demonstrated how overdetermination could be a key way of analysing multiple class processes and their economic effectivity.

5. Often valuing coherence at the expense of incoherence and messiness (DeMartino 2013; Grabel 2017).

6. A new framing of economy in no way implies that capitalist practices are not of interest to diverse economy scholars. We are concerned to research the contingencies and fragilities of what is portrayed as systemic and powerful, pulling capitalism down off its pedestal and revealing how it is assembled and made to seem durable. The chapter in this volume by Gabriel and Sarmiento (Chapter 45) discusses how genealogy is employed to this end.

7. The neologism 'capitalocentrism' is analogically related to 'phallocentrism' and 'phallogocentrism', terms coined by Jacques Derrida to highlight how the masculine (phallus) is privileged in the construction of meaning and used to productive ends by feminist post-structuralists (see Gibson-Graham 1996, Chapter 1).

8. Some have experimented with proposing a simple reversal of power whereby the subordinate 'not A' terms are elevated to a position of dominance (for example, by representing the figure of the feminine as superior to that of the masculine, or the worker-owned cooperative as superior to the private capitalist business, or socialism as superior to capitalism). The binary structure of meaning remains intact and difference is once again suppressed but in a different way.

9. We are using the phrase 'weapon of destruction' in an ironic sense here, much as Gibson-Graham did when she wrote the paper 'Waiting for the revolution, or how to smash capitalism while working at home in your spare time' (1993).

10. Showing, for example, that ' $A$ ' is $A_{1}, A_{2}, A_{3}$ and so on, and that ' $\operatorname{not} A$ ' is not $A_{1}$, not $A_{2}$, not $A_{3}$ and so on. When presence is many presences and absence is many absences, it becomes difficult to sustain any hard barrier between all the heterogeneous elements.

11. Queering is a strategy of dealignment proposed by Eve Kosofsky Sedgwick (1993) to challenge the policing of gendered identity that Gibson-Graham cross-appropriated and employed in the economic realm.

12. The iceberg image has taken on a life of its own over the years since its creation by a hybrid research collective (Community Economies Collective 2001). This simple trope of visibility/invisibility that Freud first used to distinguish the conscious from the unconscious has morphed into a floating coconut economy in the Pacific, a drinks cabinet in the UK, an ant-hill/house in South Korea. But still the iceberg is a preferred template - even becoming a 3D cardboard wearable device developed by artist Ailie Rutherford to help initiate conversations about taking back the economy in Scotland (see https://thepeoplesbankofgovanhill.wordpress.com/author/ailieprojects/page/3/ [accessed 31 July 2019]).

13. This is done with a standing invitation to researchers and activists to reclassify, rearrange, add to and elaborate it, remembering that the diverse economy inventory is decidedly not a typology to be applied in an unthinking manner. It is an ordering that has certain effects, so the researcher who employs any framing of the inventory needs to make clear what they are trying to achieve by grouping activities under certain headings.

14. Early iterations of the framing included only enterprise, labour and transactions (see, for example the discussion of a language of economic diversity in Gibson-Graham 2006, Chapter 6). Property and finance were added to the framing in Gibson-Graham et al. (2013). In the current iteration the term 'alternative' has been removed to avoid the common misconception that this framing elaborates an 'alternative economy' (see Healy 2009).

15. Many enterprises do not produce new wealth but employ people to produce services that support new wealth generation (e.g. accountancy, retailing, advertising). In the class process analysis, their operations make claims on distributed surplus payments from the direct wealth producing firms and are seen to be involved in non-class processes of surplus distribution.

16. Note the very recent passing of Modern Day Slavery Acts in the UK 2015, France 2017, and Australia 2018.

17. Recently this mobilization, or translocal contagion, has been named 'The Interdependence' and there are moves afoot for registration of a domain name (.idt) that will allow community economy initiatives to identify and be identified. 


\section{REFERENCES}

Bargh, M. (2012), 'Rethinking and re-shaping indigenous economies: Māori geothermal energy enterprises', Journal of Enterprising Communities: People and Places in the Global Economy, 6 (3), 271-83.

Barron, E. (2015), 'Situating wild product gathering in a diverse economy: Negotiating ethical interactions with natural resources', in G. Roelvink, K. St. Martin and J.K. Gibson-Graham (eds), Making Other Worlds Possible: Performing Diverse Economies, Minneapolis, MN: University of Minnesota Press, pp. 173-93.

Bonnet, F., J. Vanek and M. Chen (2019), Women and Men in the Informal Economy: A Statistical Brief, Manchester: WIEGO.

Cameron, J. and J. Hicks (2014), 'Performative research for a climate politics of hope: Rethinking geographic scale, "impact" scale and markets', Antipode: A Radical Journal of Geography, 46 (1), 53-71.

Cameron, J., C. Manhood and J. Pomfrett (2011), 'Bodily learning for a (climate) changing world: Registering differences through performative and collective research', Local Environment, 16 (6), 493-508.

Community Economies Collective (2001), 'Imagining and enacting noncapitalist futures', Socialist Review, 28 (3-4), 93-153.

Community Economies Collective and K. Gibson (2009), 'Building community-based social enterprises in the Philippines: Diverse development pathways', in A. Amin (ed.), The Social Economy: International Perspectives on Solidarity, London: Zed Press, pp. 116-38.

de Sousa Santos, B. (2014), Epistemologies of the South: Justice Against Epistemicide, Boulder, CO: Paradigm Press.

DeMartino, G. F. (2013), 'Ethical engagement in a world beyond control', Rethinking Marxism, 25 (4), 483-500.

Derrida, J. (1967), Of Grammatology, G. Spivak (trans.), Baltimore, MD: Johns Hopkins University Press.

Dombroski, K. (2016), 'Seeing diversity, multiplying possibility: My journey from post-feminism to postdevelopment with JK Gibson-Graham', in W. Harcourt (ed.), The Palgrave Handbook of Gender and Development: Critical Engagements in Feminist Theory and Practice, New York: Palgrave Macmillan, pp. 312-28.

Epstein, G. (ed.) (2005), Financialization and the World Economy, Cheltenham, UK and Northampton, MA, USA: Edward Elgar Publishing.

Escobar, A. (1995), Encountering Development: The Making and Unmaking of the Third World, Princeton, NJ: Princeton University Press.

Escobar, A. (2018), Designs for the Pluriverse: Radical Interdependence, Autonomy, and the Making of Worlds, Durham, NC: Duke University Press.

Eum, H. (2017), Cooperatives and Employment: Second Global Report, Geneva: CICOPA International Co-operative Alliance.

FAO (2015), Voluntary Guidelines for Securing Sustainable Small-Scale Fisheries in the Context of Food Security and Poverty Alleviation, Rome: Food and Agriculture Organization of the United Nations.

Gibson, K., A. Cahill and D. McKay (2010), 'Rethinking the dynamics of rural transformation: Performing different development pathways in a Philippines municipality', Transactions of the Institute of British Geographers, 35 (2), 237-55.

Gibson, K., L. Law and D. McKay (2001), 'Beyond heroes and victims: Filipina contract migrants, economic activism and class transformations', International Feminist Journal of Politics, 3 (3), 365-86.

Gibson, K., D.B. Rose and R. Fincher (eds) (2015), Manifesto for Living in the Anthropocene, New York: Punctum Books.

Gibson-Graham, J.K. (1993), 'Waiting for the revolution, or how to smash capitalism while working at home in your spare time', Rethinking Marxism, 6 (2), 10-24.

Gibson-Graham, J.K. (1996), The End of Capitalism (As We Knew It): A Feminist Critique of Political Economy, Oxford: Blackwell Publishers.

Gibson-Graham, J.K. (2000), 'Interventions', in E. Sheppard and T. Barnes (eds), A Companion to Economic Geography, Oxford: Blackwell Publishers, pp. 95-110. 
Gibson-Graham, J.K. (2002), 'Beyond global vs. local: Economic politics outside the binary frame', in A. Herod and M. Wright (eds), Geographies of Power: Placing Scale, Oxford: Blackwell Publishers, pp. 25-60.

Gibson-Graham, J.K. (2005), 'Building community economies: Women and the politics of place', in W. Harcourt and A. Escobar (eds), Women and the Politics of Place, Bloomfield, CT: Kumarian Press, pp. 130-57.

Gibson-Graham, J.K. (2006), A Postcapitalist Politics, Minneapolis, MN: University of Minnesota Press.

Gibson-Graham, J.K. (2008), 'Diverse economies: Performative practices for other worlds', Progress in Human Geography, 32 (5), 613-32.

Gibson-Graham, J.K., J. Cameron, K. Dombroski, S. Healy, E. Miller and the Community Economies Collective (2017), 'Cultivating community economies: Tools for building a liveable world', in G. Alperovitz and J. G. Speth (eds.), The Next System Project, accessed 29 July 2019 at http:// thenextsystem.org/cultivating-community-economies/.

Gibson-Graham, J.K., J. Cameron and S. Healy (2013), Take Back the Economy: An Ethical Guide for Transforming our Communities, Minneapolis, MN: University of Minnesota Press.

Gibson-Graham, J.K., A. Hill and L. Law (2016), 'Re-embedding economies in ecologies: Resilience building in more than human communities', Building Research Information, 44 (7), 703-36.

Grabel, I. (2017), When Things Don't Fall Apart: Global Financial Governance and Developmental Finance in an Age of Productive Incoherence, Cambridge, MA: MIT Press.

Harvey, D. (1973), Social Justice and the City, Baltimore, MD: Johns Hopkins University Press.

Healy, S. (2009), 'Economies, alternative', in R. Kitchin and N. Thrift (eds), International Encyclopaedia of Human Geography, Volume 3, Oxford: Elsevier, pp. 338-43.

Hirschman, A.O. (1971), A Bias for Hope: Essays on Development and Latin America, New Haven, CT: Yale University Press.

Hirschman, A.O. (2013 [1971]), 'Political economics and possibilism', in J. Adelman (ed.), The Essential Hirschman, Princeton, NJ: Princeton University Press, pp. 1-34.

Kothari, S. and W.J.D. Harcourt (2004), 'Introduction: The violence of development', Development, 47 (1), 3-7.

Laclau, E. and C. Mouffe (1985), Hegemony and Socialist Strategy, London: Verso.

Latour, B. (2014), 'Some advantages of the notion of "Critical Zone" for geopolitics', Procedia Earth and Planetary Science, 10, 3-6.

Leyshon, A. (2010), 'Classics in human geography revisited: Gibson-Graham, J.K. 1996: The End of Capitalism (As We Knew It): A Feminist Critique of Political Economy. Oxford: Blackwell', Commentary 2, Progress in Human Geography, 34 (1), 120-122.

Madra, Y. M. (2006), 'Questions of communism: Ethics, ontology, subjectivity', Rethinking Marxism, $18(2), 205-24$.

Marston, S., J.P. Jones III and K. Woodward (2005), 'Human geography without scale', Transactions of the Institute of British Geographers, 30 (4), 416-32.

Mason, P. (2016), Postcapitalism: A Guide to Our Future, Basingstoke: Macmillan.

Mazzucato, M. (2011), 'The entrepreneurial state', Soundings, 49 (Winter), 131-42.

Miller, E. (2019), Reimagining Livelihoods: Life Beyond Economy, Society and the Environment, Minneapolis, MN: University of Minnesota Press.

Morrow, O. and K. Dombroski (2015), 'Enacting a postcapitalist politics through the sites and practices of life's work', in K. Meehan and K. Strauss (eds), Precarious Worlds: Contested Geographies of Social Reproduction, Athens, GA: University of Georgia Press, pp. 82-98.

Nancy, J.-L. (1991), 'Of being-in-common', in Miami Theory Collective (ed.), Community at Loose Ends, Minneapolis, MN: University of Minnesota Press, pp. 1-12.

Niehof, A. (1998), 'The changing lives of Indonesian women: Contained emancipation under pressure', Bijdragen tot de taal-, land-en volkenkunde/Journal of the Humanities and Social Sciences of Southeast Asia, 4 (2), 236-58.

Plumwood, V. (2007), 'A review of Deborah Bird Rose's reports from a wild country: Ethics for decolonisation', Australian Humanities Review, 42, 1-4.

Raworth, K. (2017), Doughnut Economics: Seven Ways to Think Like a 21st-Century Economist, London: Random House.

Resnick, S.A. and R.D. Wolff(1986), 'Power, property and class', Socialist Review, 86 (Spring), 97-124. 


\section{The handbook of diverse economies}

Resnick, S.A. and R.D. Wolff (1987), Knowledge and Class: A Marxian Critique of Political Economy, Chicago and London: University of Chicago Press.

Robertson, G. (2018), Budget 2019: Budget Policy Statement, Wellington: New Zealand Government.

Roelvink, G. and M. Zolkos (2015), 'Affective ontologies: Post-humanist perspectives on the self, feeling and intersubjectivity', Emotion Space and Society, 14, 47-9.

Ruccio, D. (1998), 'Deconstruction', in J.B. Davis, D.W. Hands and U. Maki (eds), The Handbook of Economic Methodology, Cheltenham, UK and Northampton, MA, USA: Edward Elgar Publishing, pp. 89-93.

Safri, M. and J. Graham (2010), 'The global household: Toward a feminist postcapitalist international political economy', Signs 40, 99-125.

Sedgwick, E.K. (1993), Tendencies, Durham, NC: Duke University Press.

Sepie, A. (2017), 'More than stories, more than myths: Animal/human/nature(s) in traditional ecological worldviews', Humanities, 6 (4), 78.

Spencer, K. (2018), 'Some millenials aren't saving for retirement because they believe capitalism will not exist by then', Salon, 18 March, accessed 29 July 2019 at https://www.salon.com/2018/03/18/some -millennials-arent-saving-for-retirement-because-they-do-not-think-capitalism-will-exist-by-then/.

St. Martin, K., G. Roelvink and J.K. Gibson-Graham (2015), 'An economic politics for our times', in G. Roelvink, K. St. Martin and J.K. Gibson-Graham (eds), Making Other Worlds Possible: Performing Diverse Economies, Minneapolis, MN: University of Minnesota Press, pp. 1-25.

Steffen, W., W. Broadgate, L. Deutsch, O. Gaffney and C. Ludwig (2015), 'The trajectory of the Anthropocene: The great acceleration', The Anthropocene Review, 2 (1), 81-98. 